\title{
Preparation of Graphene-Polyaniline-Cellulose Double Network Hydrogels Using One Pot Method by Gamma Irradiation with Electrochemical Properties
}

\author{
Deni Swantomo ${ }^{1,}$, Kris Tri Basuki ${ }^{1}$, Sigit $^{2}$, and Yadi Yunus ${ }^{1}$ \\ ${ }^{1}$ Polytechnic Institute of Nuclear Technology, National Nuclear Energy Agency, \\ Jl. Babarsari Kotak Pos 6101 YKBB, Yogyakarta 55281, Indonesia \\ ${ }^{2}$ Center for Nuclear Fuel Technology, National Nuclear Energy Agency, \\ Kawasan Puspiptek Serpong, Tangerang 15314, Indonesia
}

Received November 21, 2017; Accepted February 13, 2018

\begin{abstract}
In order to achieve high performance of electrochemical properties, numerous efforts have been devoted to the development of advanced multi-component hybrid double network hydrogel materials. In this research, the double network hydrogels were synthesized using one pot method by graft copolymerization of aniline onto graphene and cellulose using gamma irradiation as initiator. The formation of the double network hydrogels was confirmed by the Fourier Transform Infrared Spectroscopy (FTIR) study. X-ray Diffraction (XRD) analysis showed that the crystalline was increased through graft copolymerization graphene-aniline-cellulose double network. It was found that the crosslink density increased with increasing aniline volume and increasing radiation doses inversely with the swelling degree. Electrochemical measurements exhibited that increasing aniline volume and radiation doses increased specific capacitance and conductivity of the hydrogels. When compared with the pure graphene, the synthesized double network hydrogels exhibits remarkably enhanced specific capacitance of $9.774 \mathrm{~F} \mathrm{~g}^{-1}$ and conductivity i.e. $4.766 \times 10^{-2} \mathrm{Scm}^{-1}$ in $0.5 \mathrm{M} \mathrm{HCl}$ solution at aniline volume $8 \mathrm{~mL}$ and radiation dose $80 \mathrm{kGy}$. The improved electrochemical properties of the double network hydrogels represented an alternative promising candidate for the application as energy storage devices and offered a new facile method.
\end{abstract}

Keywords: double network hydrogels; aniline; graphene; electrochemical properties; gamma irradiation

\section{ABSTRAK}

Untuk mencapai kinerja sifat elektrokimia yang tinggi, berbagai usaha telah dilakukan untuk pengembangan material hidrogel hybrid struktur jaringan ganda multi komponen. Dalam penelitian ini, hidrogel struktur jaringan ganda telah disintesis menggunakan metode satu pot dengan kopolimerisasi grafting anilin ke graphene dan selulosa menggunakan irradiasi gamma sebagai inisiator. Terbentuknya hidrogel struktur jaringan ganda berhasil dibuktikan dari hasil analisis Fourier Transform Infrared Spectroscopy (FTIR). Analisis X-ray difraksi (XRD) menunjukkan bahwa kristalinitas meningkat dengan adanya kopolimerisasi grafting struktur jaringan ganda graphene-anilin-selulosa. Hasil penelitian menunjukkan bahwa densitas ikatan silang meningkat dengan meningkatnya volume anilin dan peningkatan dosis radiasi serta berbanding terbalik dengan derajat swelling. Pengukuran sifat elektrokimia menunjukkan bahwa peningkatan volume anilin dan dosis radiasi mampu meningkatkan kapasitansi spesifik dan konduktivitas hidrogel. Bila dibandingkan dengan graphene, hidrogel struktur jaringan ganda yang telah disintesis menunjukkan peningkatan kapasitansi spesifik yang sangat tinggi yaitu 9,774 $F$ $\mathrm{g}^{-1}$ dan konduktivitasnya yaitu 4,766 $\times 10^{-2} \mathrm{Scm}^{-1}$ dalam larutan $\mathrm{HCl} 0,5 \mathrm{M}$, volume anilin $8 \mathrm{~mL}$ dan dosis radiasi 80 kGy. Peningkatan sifat elektrokimia pada hidrogel struktur jaringan ganda menjadikan sebagai kandidat alternatif yang menjanjikan untuk aplikasi sebagai perangkat penyimpanan energi dan menawarkan metode baru yang mudah.

Kata Kunci: hidrogel struktur jaringan ganda; anilin; graphene; sifat elektrokimia; irradiasi gamma

\section{INTRODUCTION}

Over the past decades polymeric hydrogels become subject of great interest due to their wide range of applications, such as controlled release fertilizer [1-2], drug delivery system [3], tissue engineering scaffold [4], electroconductive materials [5], and bioelectronics [6]. Hydrogels are three-dimensionally cross linked hydrophilic polymers network capable of swelling and retaining huge volumes of water in the swollen state

* Corresponding author.

Email address : deni@sttn-batan.ac.id

DOI: 10.22146/ijc.30467 
[1,7-8]. Currently, the further extension of application of hydrogels was limited because most of the hydrogels show low toughness and stiffness. To improve these limitations, many researches have been done to improve its strength and stiffness properties through various nanocomposite synthesized and double network (DN) formed [9-13]. DN hydrogels are new class of polymeric hydrogels which consists of two interpenetrating polymer networks that interpenetrated in each other. The primary network is densely cross-linked, rigid, and brittle polymer while the second network is a loosely cross-linked soft and ductile polymer [12,14]. Most DN hydrogels have higher mechanical strength and toughness than single network hydrogels.

Recently, DN hydrogels based on conducting polymers have been extensively explored. It has been shown that conductivity may also be introduced to hydrogels by synthesizing conducting polymers (CPs) into a preformed hydrogels network to form a double interpenetrating polymer network. The combination properties of cross-linked hydrogels with CPs may lead to the preparation of multifunctional electrical conducting materials such as biosensor [15-16], biomedical electrodes [12,17], energy storage devices batteries [18] and supercapacitors [19]. In energy storage application, DN hydrogels should have high capacitance and conductivity. Various hybrid materials based on chemically modified graphene materials with CPs such as polypyrrole and polyaniline (PANi) have been used in energy storage devices for achieving high capacitance and conductivity [20-22]. These hybrid materials have been found to increase electrochemical properties due to synergistic effects between electric double-layer capacitor behavior of graphene and pseudo capacitor behavior of CPs. Graphene, a single layer of $\mathrm{sp}^{2}$ hybridized carbon atoms, has particularly been a good candidature as conductive hydrogels for energy storage device owing to its large surface area, mechanical strength, high electron mobility $[6,12,14]$. Moreover, graphene is suitable for grafting or crosslinking with various CPs through hydrogen interaction and surface grafting. PANi is considered as a promising CPs for energy storage device because of conjugate nature with $\mathrm{sp}^{2}$ hybridization, relatively high conductivity, easy synthesis, high flexibility and multi-redox state. As most abundant biopolymer resource, cellulose is promising candidates for conjunction with conductive active materials such as graphene [23-24], carbon nanotubes [25], PANi [26], polypyrrole [27] because of its flexibility, high mechanical strength, lightweight, inexpensive, and biodegradable. Nowadays there has been a growing interest in modification of graphene with a double network hydrogels to achieve high performance of electrochemical properties. Ma et al. [28] prepared conductive film based on polypyrrole/bacterial cellulose/graphene paper with improved capacitance and flexibility. lakobson et al. [29] reported that increasing of conductivity could be achieved after graphene introduction into polyaniline-polyacid hydrogels.

Generally, DN hydrogels synthesized using twostep sequential free-radical polymerization process in which the process is very time consuming because of diffusion time of the second monomer and two polymerization processes. Therefore simple one-pot synthesis method is needed to overcome these drawbacks. The one-pot method involves sequential multiple in situ polymerization reactions of hydrogel precursor reactants taking place in one reactor. Researchers reported number DN hydrogels by onepot synthesis methods such as using physical crosslinking [11], chemical graft copolymerization and crosslinking [12,16,30], photo cross-linked [13], microwave assisted graft copolymerization [31], graft copolymerization by gamma radiation [32-33]. Among these methods, gamma radiation induced graft copolymerization promoted the efficient preparation of DN hydrogels due to characteristic of high energy, large penetration with uniform formation of free radicals, rapid and easily controlled, and easy scaledup production.

Synthesis and characterization of graphene DN hydrogels based on different polymeric backbones with various methods have previously been reported. However, until now no researcher has reported a comprehensive gamma radiation synthesis and characterization of DN hydrogels based on graphenepolyaniline-cellulose with electrochemical properties. In the present study, the synthesis and characterization of DN hydrogels based on graphene-polyaniline-cellulose using one-pot method by simultaneous gamma irradiation technique were reported. Further, the effects of aniline and radiation dose on electrochemical properties i.e. specific capacitance and conductivity have been investigated.

\section{EXPERIMENTAL SECTION}

\section{Materials}

Celluloses were isolated from seaweed using alkali treatment by $5 \%$ aqueous $\mathrm{NaOH}$ solutions. Aniline and ammonium persulfate (APS) pure analysis grade were obtained from Merck product. Sodium hydroxide, acetone, demineralized water, ethanol, $\mathrm{H}_{2} \mathrm{SO}_{4}$ were technical grade. 


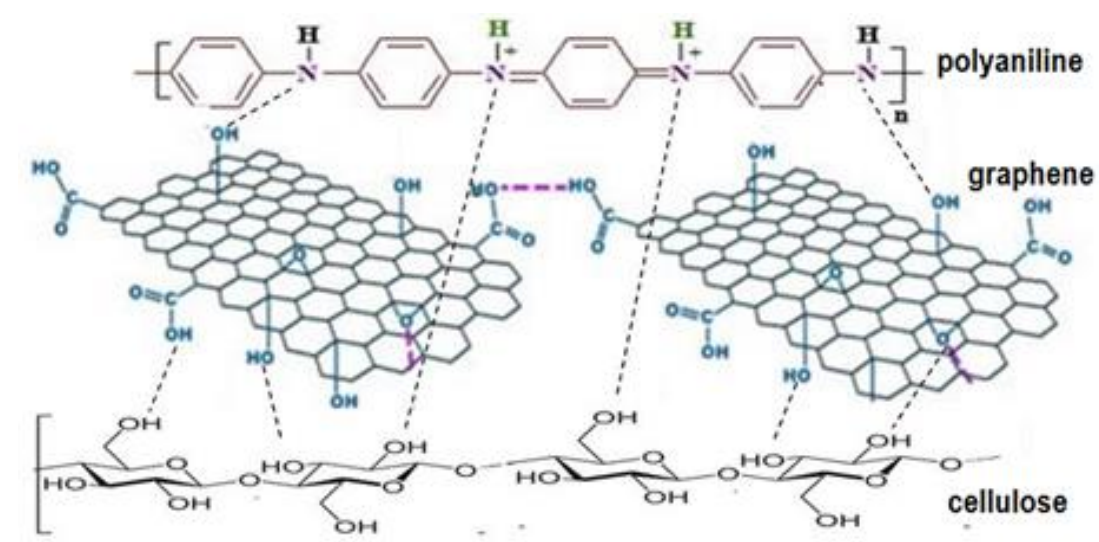

Fig 1. Proposed schematic of crosslinking between graphene-polyaniline-cellulose

\section{Instrumentation}

Volumetric glasses were used for preparing reagent, aniline, cellulose and graphene. Gamma Chamber-40 was used for irradiation sample. The double networks Hydrogels were characterized using Thermo Nicolet Avatar FTIR spectrophotometer and Xray diffractometer Shimadzu type 6000. Metrohm Autolab was used to analysis the electrochemical properties.

\section{Procedure}

Preparation of graphene-polyaniline-cellulose DN hydrogels using gamma irradiation

The graphene oxide powder was synthesized from graphite based on a modified Hummer method [9,12]. Prior to the graft co-polymerization reaction, $3 \mathrm{~g}$ graphene oxide was dissolved in $20 \mathrm{~mL}$ of distilled water for $6 \mathrm{~h}$ for the better dispersion. Three grams cellulose and various amounts aniline i.e. $0,6,8,10$, and $12 \mathrm{~mL}$ were added into the mixture and for $8 \mathrm{~h}$ dispersed ultrasonically to form a homogeneous solution. The mixture was then poured into aluminum tube and irradiated with gamma radiation using Gamma Chamber40 with various radiation doses in atmospheric conditions and at room temperature. The resulting graphene-polyaniline-cellulose graft copolymer was washed with distilled water and separated from unreacted monomers as well as homopolymers using centrifuge. Finally, the DN hydrogel was dewatered with acetone and dried in a hot air oven at $40{ }^{\circ} \mathrm{C}$ for $24 \mathrm{~h}$. The proposed reaction mechanism is illustrated in Fig. 1. Polyaniline homopolymer was synthesized by radiolytic synthesis method for comparison with the DN hydrogels. In this method, the aqueous solution of aniline and APS in $\mathrm{HCl}$ was irradiated with gamma rays without any template.

\section{Characterization measurements of graphene-polyaniline-cellulose DN hydrogels}

Fourier Transform Infrared Spectroscopy (FTIR) analyses were done using a Thermo Nicolet Avatar FTIR spectrophotometer in order to study the formation of DN hydrogels. X-Ray Diffraction (XRD) studies were performed under ambient conditions, using a Shimadzu XRD-6000 X-ray diffractometer. To investigate the swelling behavior, the dried hydrogels were immersed in deionized water for $48 \mathrm{~h}$ at room temperature on a mixer and the hydrogels were filtered. This method refers to the Japanese Industrial Standard K8150 [34]. The swelling degree is calculated as shown in Eq. (1). swelling degree $=\frac{W_{s s}-W_{d}}{W_{d}} \times 100 \%$

where $W_{\text {ss }}$ is the weight of the hydrogel in swollen state and $W_{d}$ is the weight of the hydrogel in dried state. The crosslink density of DN hydrogels was determined using the Flory-Rhener theory by equilibrium swelling theory and it is expressed in Eq. (2) [34-35].

$\rho_{\mathrm{e}}=\frac{\left[\ln \left(1-\mathrm{v}_{2, \mathrm{~s}}\right)+\mathrm{v}_{2, \mathrm{~s}}+\chi_{1}\left(\mathrm{v}_{2, \mathrm{~s}}\right)^{2}\right] / \mathrm{v}_{1}}{\left(\mathrm{v}_{2, \mathrm{~s}}{ }^{1 / 3}-\frac{\mathrm{v}_{2, \mathrm{~s}}}{2}\right)}$

where $X_{1}$ is Flory-Huggines polymer-solvent dimensionless interaction, $V_{1}$ is the molar volume of solvent, and $\mathrm{U}_{2, \mathrm{~s}}$ is the polymer volume fraction in the swollen state that is the reciprocal of the volumetric swollen ratio $(Q)$ which relates to the densities of the solvent $\left(\rho_{\mathrm{s}}\right)$ and polymer $\left(\rho_{\mathrm{p}}\right)$ and mass swollen ratio $\left(Q_{m}\right)$ as given by Eq. (3).

$$
v_{2, s}=Q^{-1}=\frac{1 / \rho_{p}}{Q_{m} / \rho_{s}+1 / \rho_{p}}
$$

Electrochemical characterizations were carried out using Metrohm Autolab with conventional three electrode measurement system using platinum plate as 
counter electrode and $\mathrm{Ag} / \mathrm{AgCl}$ as reference electrode and the DN hydrogels was used as working electrode. The measurements were performed in $0.5 \mathrm{M} \mathrm{HCl}$ aqueous electrolyte at room temperature. The specific capacitance was calculated using Eq. (4).

$$
\mathrm{C}=\frac{\mathrm{I} \times \mathrm{t}}{\Delta \mathrm{V} \times \mathrm{m}}
$$

where, $\mathrm{C}, \mathrm{I}, \mathrm{t}, \Delta \mathrm{V}$, and $\mathrm{m}$ are the specific capacitance, charge/discharge current, charge/discharge time, the potential difference, and the total mass of the DN hydrogels electrode respectively.

\section{RESULT AND DISCUSSION}

\section{Structures Characterization of Graphene- Polyaniline-Cellulose DN Hydrogels Using FTIR Spectroscopy and XRD}

FTIR analysis was used to evaluate the success of graphene-polyaniline-cellulose DN hydrogels grafting by comparing the functionality of the original cellulose, polyaniline, and graphene oxide with that of the DN hydrogels. Fig. 2 presents the FTIR spectra of cellulose, polyaniline, graphene oxide, and graphene-polyanilinecellulose DN hydrogels.

The graphene oxide spectrum evidently display the presence of $\mathrm{O}-\mathrm{H}$ stretching, $\mathrm{C}=\mathrm{O}$ stretching, $\mathrm{O}-\mathrm{H}$ deformation vibration, $\mathrm{C}-\mathrm{O}$ stretching in $\mathrm{C}-\mathrm{O}-\mathrm{C}$, and $\mathrm{C}-\mathrm{O}$ stretching in $-\mathrm{C}-\mathrm{OH}$ functional group, indicated by the broad absorption band at around 3415, 1729, 1384, 1245 , and $1051 \mathrm{~cm}^{-1}$. These spectrums are in good agreement with previous FTIR spectroscopic characterizations of graphene [12,22]. Polyaniline has characteristic FTIR spectra, as reported elsewhere [3638] at 1527 and $1382 \mathrm{~cm}^{-1}$ which are assigned to $\mathrm{C}=\mathrm{N}$ stretching vibrations of the quinonoid ring and $\mathrm{C}-\mathrm{N}$ stretching in the quinonoid-benzenoid, respectively. For the cellulose, the spectra present characteristic FTIR peaks at $3480 \mathrm{~cm}^{-1}, 1657 \mathrm{~cm}^{-1}$, and bands in the range of $800-1150 \mathrm{~cm}^{-1}$, which are correspond to $\mathrm{O}-\mathrm{H}$ stretching, C-O-C stretching, and glycosidic $\mathrm{C}-\mathrm{H}$ deformation of aloxy group of cellulose. In Fig. 2, one can see that after introduction of polyaniline and cellulose in graphene there are some shifts in band position with changes in the absorption band intensity and several new peaks compared to graphene. The stretching vibration of $\mathrm{O}-\mathrm{H}$ at around $3415 \mathrm{~cm}^{-1}$ has been shifted to shorter wavenumbers and broader at $3006 \mathrm{~cm}^{-1}$ indicating that the graft crosslinking reaction of graphene, polyaniline and cellulose occurred via hydrogen bonding. This observation was similar to cellulose nanofibers-graphene composite [23], the crosslinked porous cellulose with graphene [39], and polyaniline-grafted reduced graphene oxide [38]. The interaction of graphene with imine groups $(\mathrm{C}=\mathrm{N})$ in the

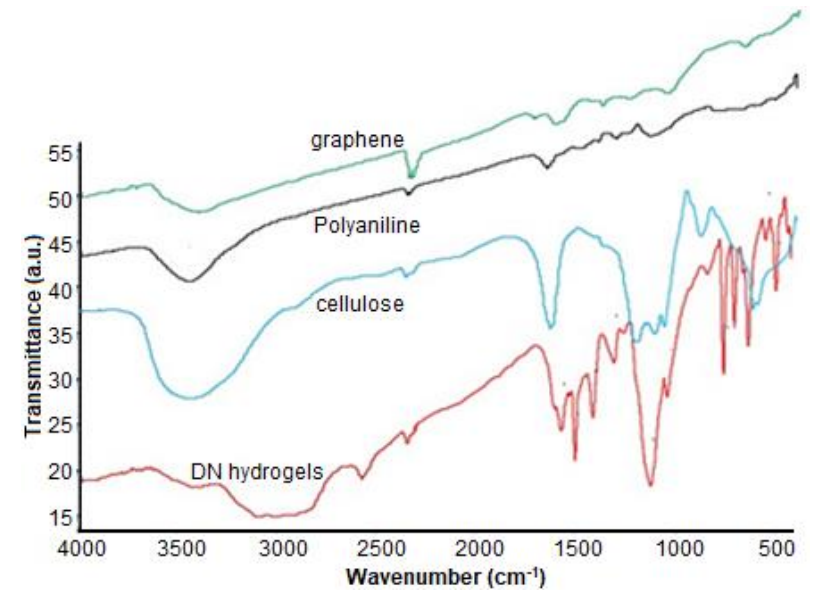

Fig 2. FTIR spectra of graphene, polyaniline, cellulose, and the DN hydrogels

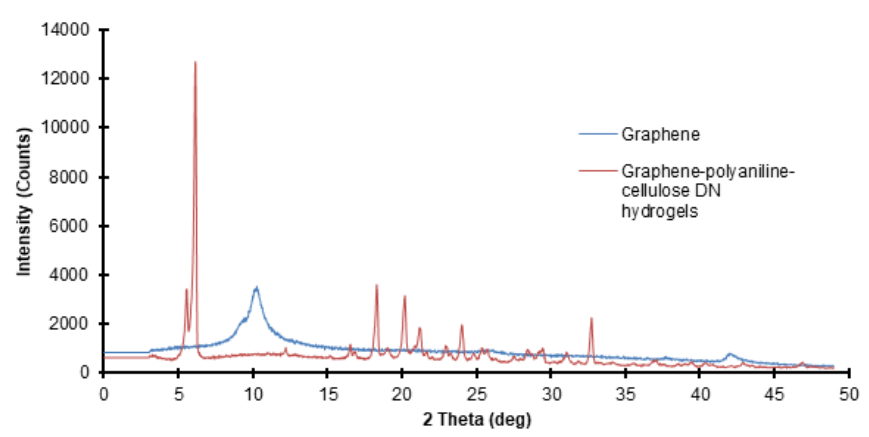

Fig 3. X-ray diffractograms of graphene and the DN hydrogels

quinonoid ring of polyaniline is proved by the shift of the initial position of the band from 1527 to $1464 \mathrm{~cm}^{-1}$. This shift could be deduced that the chemical interaction between graphene and polyaniline was linked from the carboxyl group of graphene to the nitrogen of the polyaniline backbone. Ameen et al. [37] also found that the shifting band of imine groups indicates the interaction between graphene and polyaniline through $\pi-\pi$ interactions by partial hydrogen bonding during the in situ electrochemical polymerization. The new absorption band at $1301 \mathrm{~cm}^{-1}$ appeared from interaction of $\mathrm{C}-\mathrm{N}$ stretching vibration with the $\mathrm{CHN}$ deformation vibration which ensures bonding of graphene with cellulose. The FTIR spectrum of the DN hydrogels is dominated by that of cellulose that shown in the range of $800-1150 \mathrm{~cm}^{-1}$. These results clearly support our hypothesis that the graphene-polyaniline-cellulose DN hydrogels were successfully prepared by gamma irradiation.

In conjunction with FT-IR spectroscopy, X-Ray Diffraction was analyzed to give a more complete data of ordered structures of graphene oxide and the graphene-polyaniline-cellulose DN hydrogels as shown in Fig. 3. 
The XRD patterns of graphene oxide reveal a characteristic diffraction peak at $2 \theta=10.06^{\circ}$ which is corresponding to the interplanar spacing of graphene oxide sheets. Several new intense and sharp peaks of graphene-polyaniline-cellulose DN hydrogels are located at $2 \theta$ values of $6.12,20.12$, and $23.98^{\circ}$ which correspond to the characteristic diffraction peak of polyaniline in its emeraldine salt form. The characteristic diffraction peak of cellulose at $2 \theta=18.3$ and $21.14^{\circ}$ as shown in our previous research [34] also include in XRD patterns of the DN hydrogels. According to the XRD spectra the characteristic diffraction peak of graphene oxide at $2 \theta=10.06^{\circ}$ completely disappears in the DN hydrogels. This could imply that the DN hydrogels fully formed homogenous with no aggregation formed of graphene. The similar results were found in the XRD spectra of graphene-cellulose composites [39] and polyaniline-graphene grafted [38]. Moreover, the diffraction of graphene-polyaniline-cellulose DN hydrogels is of stronger and sharper intensity compared to graphene which indicate increasing the crystallinity. Therefore, the XRD results confirm the formation of the DN hydrogels which the result is consistent with the FTIR results.

\section{Effect of Aniline on Crosslink Density and Swelling}

The crosslink density is important network structure properties of DN hydrogels that is strongly factor affecting the swelling properties. The effects of aniline on crosslink density and swelling were studied at different volume while other influential factors were maintained constant and the results are given in Table 1.

The results reveal that the crosslink density increased with increased aniline volume then tended to level off around $10 \mathrm{~mL}$. It might seem that the crosslink density of graphene-polyaniline-cellulose DN hydrogels was significantly higher than that of graphene-cellulose singular network hydrogels. Increasing of the crosslink density might be caused increasing in crosslink density of the second network and the polymer chains content of the DN hydrogels. Increasing volumes of aniline monomer, the free radicals come closer that tends to form more cross-links. Furthermore, increasing the second monomer would cause more crosslink point and higher crosslink density. The slightly increasing of crosslink density in higher aniline volume is due to that not all of the active sites polyaniline functioned as the second polymer network. At higher aniline volume, the polyaniline homopolymerization is predominantly because of cyclization and steric effects which similar results were reported by other researchers $[8,10,31]$.

The swelling degree is one of the most important properties of DN hydrogels to evaluate the amount of absorbed water. As can be seen from Table 1, the results
Table 1. Effect of aniline volume on crosslink density and swelling

\begin{tabular}{ccc}
\hline $\begin{array}{c}\text { Aniline volume } \\
{[\mathrm{mL}]}\end{array}$ & $\begin{array}{c}\text { Crosslink density } \\
{\left[\mathrm{mol} / \mathrm{cm}^{3}\right]}\end{array}$ & $\begin{array}{c}\text { Equilibrium swelling } \\
\text { degree [\%] }\end{array}$ \\
\hline 0 & 0.00354 & 176.6 \\
6 & 0.02446 & 202.9 \\
8 & 0.02976 & 250.1 \\
10 & 0.05902 & 155.8 \\
12 & 0.05985 & 148.4 \\
\hline
\end{tabular}

indicate that initial increasing aniline volume in the range 6 to $8 \mathrm{~mL}$ increase swelling degree. However, the swelling degree has been decreased by aniline volume further increased. According to Omidian et al. [35], Mittal et al. [31], and Mohammadi et al. [12], swelling behaviors of hydrogels relate to the crosslink density, strength of the hydrophilic group, and elasticity of the polymer network. It is shown that the initial increasing of swelling degree could be attributed predominance increasing hydrophilic groups of the DN hydrogels which is caused by increased interpenetrated network structure as the result of aniline addition. The hydrophilic groups of the DN hydrogels also can be enhanced using acrylamide [32], gelatin [12] and acrylic acid [33]. Further increasing aniline resulted in the predominance of higher crosslink density as shown in Table 1 . This can make decreasing free space volume available in the network structure hydrogels for absorption the amount of water molecules. Moreover, increasing the crosslink density increases rigidity and tightness of the network structures DN hydrogels thus restricts the relaxation of macromolecular chains towards a lower swelling degree. Sharma et al. [33] and Mohammadi et al. [12] also reported that higher crosslink density could decrease the water absorbency of the DN hydrogels.

\section{Effect of Aniline on Capacitance and Conductivity}

The electrochemical properties such as specific capacitance and conductivity are the most important property of DN hydrogels as energy storage devices. The specific capacitance and conductivity for various aniline volumes in dilute $0.5 \mathrm{M} \mathrm{HCl}$ aqueous electrolyte are summarized in Table 2.

The experimental results showed that the specific capacitance of the graphene-polyaniline-cellulose DN hydrogels is enhanced significantly compared with graphene-cellulose hydrogels. With increasing aniline volume from 0 to $8 \mathrm{~mL}$, the specific capacitance has obvious enhancement. However, the specific capacitance tended to level off by aniline volume further increased. Increasing specific capacitance after in situ copolymerization grafting aniline on graphenecellulose structure mainly results due to the synergetic contribution of both double layers from graphene and 
Table 2. Effect of aniline volume on specific capacitance and conductivity

\begin{tabular}{ccc}
\hline $\begin{array}{c}\text { Aniline volume } \\
{[\mathrm{mL}]}\end{array}$ & $\begin{array}{c}\text { Specific } \\
\text { Capacitance }[\mathrm{F} / \mathrm{g}]\end{array}$ & $\begin{array}{c}\text { Conductivity } \\
{[\mathrm{S} / \mathrm{cm}]}\end{array}$ \\
\hline 0 & 0.062 & $0.603 \times 10^{-2}$ \\
6 & 0.969 & $1.055 \times 10^{-2}$ \\
8 & 1.647 & $2.012 \times 10^{-2}$ \\
10 & 1.410 & $1.891 \times 10^{-2}$ \\
12 & 1.412 & $1.974 \times 10^{-2}$ \\
\hline
\end{tabular}

pseudo-capacitance from polyaniline. The linked of polyaniline with graphene-cellulose network through strong $\pi-\pi$ interactions by partial hydrogen bonding as shown in the FTIR spectra could provide a better conducting networks, that supports the redox reaction and improve the capacitance. These enhanced specific capacitances also could be supported by hydrophilic properties of polyaniline according to the Fig. 2 and free volume structures in the DN hydrogels thus it increased direct interaction the $\mathrm{HCl}$ aqueous electrolyte with the internal electroactive structures. Similarly the synergetic results were observed for polyaniline-grafted reduced graphene oxide [38], polypyrrole wrapped graphene hydrogels [20], PANI-polyacid/graphene nanocomposite [29], polyaniline-graphene hydrogels [21], and polypyrrole/bacterial cellulose/graphene paper [28]. When the aniline volume further increased over $8 \mathrm{~mL}$, the specific capacitance no longer increased. The reason might be caused the redundant aniline tended to aggregate formed because of cyclization and steric effects polyaniline homopolymers. The aggregate formed leads deteriorated the network structures framework hydrogels thus decrease the specific capacitance due to lowered ion transport diffusion [20]. The densely crosslink as shown in Table 1 also could contribute difficulty transferring charge transfer and ion transport across the DN hydrogels therefore the pseudocapacitance contribution was limited at higher aniline volume.

From Table 2, it can be seen that the electrical conductivity of the DN hydrogels was influenced by aniline volume. The results show that conductivity of the graphene-polyaniline-cellulose DN hydrogels is evidently higher than of graphene-cellulose hydrogels which continuously increased with the increasing aniline volume up to $8 \mathrm{~mL}$. The higher conductivity of the DN hydrogels might be attributed to the $\pi-\pi$ conjugated structure between polyaniline chains with graphene hydrogels which higher charger-transport paths were formed thus the conductivity increases. These enhanced also could be contributed by the homogenous formed of graphene in the DN hydrogels and increasing the crystallinity with polyaniline attachment to the hydrogels structures which were confirmed by the XRD result in Fig. 3. Increased crystallinity in the DN hydrogels enhances interchain electron mobility which occurs in ordered structures crystalline regions, and improves interchain electron coupling. As a result, increasing the conductivity can be obtained by increasing crystallinity and this phenomenon is discussed in detail by Moghadam et al. [40]. Various studies [21,27-29] have substantially reported swelling properties to increase its conductivity. The presence of the swelling structures in the DN hydrogels offers an additional interface between the DN hydrogels and the $\mathrm{HCl}$ aqueous electrolyte. Highly swollen structures can facilitate diffusion channels for electron transport and improve access of electrolyte ions to electroactive sites of the DN hydrogels. The conductivity of the DN hydrogels slightly decreased when aniline volume further increased to $12 \mathrm{~mL}$. As the explanation above, the aggregate formed structures were obtained at aniline volume above $8 \mathrm{~mL}$. These structures lead increasing resistance value due to lower electron diffusion transport.

\section{Effect of Radiation Doses on Crosslink Density and Swelling}

The crosslink density and equilibrium swelling degree were evaluated with different irradiation doses ranging from 40 to $100 \mathrm{kGy}$ as shown in Table 3.

Increasing of the crosslink density with increasing radiation dose from 40 to $80 \mathrm{kGy}$ can be observed in Table 3 then tended to slightly decrease by radiation dose further increased. In simultaneous gamma irradiation of aqueous polymer solution, aniline monomer radicals and active sites on the graphene and cellulose backbone are simultaneously generated by the initiating energy of gamma radiation. The formation of macro-radicals on the polymer chains mainly due to hydroxyl radicals from radiolysis of water molecules attack the polymer chains which can recombine as cross-linked structure of the DN hydrogels. An increase in the radiation dose enhances the formation of radicals on the polymeric chains and formation of a large number of smaller and closer macro radicals that led the formation of more compact network structure caused of higher initiating energy. In turn, this process causes increasing crosslink density of the DN hydrogels. However, a slightly decrease in crosslink density was observed when the radiation dose further increased to $100 \mathrm{kGy}$. Both crosslinking and chain scission of polymers occurs simultaneously on gamma irradiation of macromolecule polymers with conversion rate depending on the radiation doses $[33,41]$. After reaching an optimum, increasing radiation dose leads the more dominating contribution of chain scission than crosslinking formed and results in degradation and breaking the network structure. Therefore, the crosslink density was slightly decreased, 
Table 3. Effect of radiation doses on crosslink density and swelling

\begin{tabular}{ccc}
\hline $\begin{array}{c}\text { Radiation doses } \\
\text { [kGy] }\end{array}$ & $\begin{array}{c}\text { Crosslink density } \\
{\left[\mathrm{mol} / \mathrm{cm}^{3}\right]}\end{array}$ & $\begin{array}{c}\text { Equilibrium swelling } \\
\text { degree [\%] }\end{array}$ \\
\hline 40 & 0.02976 & 250.1 \\
60 & 0.06263 & 144.5 \\
80 & 0.09082 & 128.4 \\
100 & 0.08007 & 130.2 \\
\hline
\end{tabular}

Table 4. Effect of radiation doses on specific capacitance and conductivity

\begin{tabular}{ccc}
$\begin{array}{c}\text { Radiation Doses } \\
{[\mathrm{kGy}]}\end{array}$ & $\begin{array}{c}\text { Specific } \\
\text { Capacitance }[\mathrm{F} / \mathrm{g}]\end{array}$ & $\begin{array}{c}\text { Conductivity } \\
{[\mathrm{S} / \mathrm{cm}]}\end{array}$ \\
\hline 40 & 1.647 & $2.012 \times 10^{-2}$ \\
60 & 5.085 & $4.583 \times 10^{-2}$ \\
80 & 9.774 & $4.766 \times 10^{-2}$ \\
100 & 9.681 & $4.751 \times 10^{-2}$ \\
\hline
\end{tabular}

which this similar results were reported earlier both for gamma [34] and electron beam irradiation [8].

As the result shown in Table 3, equilibrium swelling degree of the DN hydrogels decreased with increasing radiation dose and leveled off in the range of 80 to 100 kGy. The swelling degree indicates the extent of the cross-linking in hydrogels structures, thus the crosslink density can arrange swelling properties as the previous discussion. The radiation doses increment increases the number of intermolecular crosslinks which leads to the formation of the more compact network structure of the DN hydrogels. This result decreases free volume in the crosslinking networks for the water absorbency or swelling processes. It is also found that highly crosslinked hydrogels with more chemical network bonds connected enhances the dispersing force and the molecular force. These forces restrict mobility of the network chains to expand and hold large quantities of water. The slightly increase of swelling with further increasing radiation doses can be caused the breaking of the network structure, in turn increases the free volume of the DN hydrogels. Degradation and breaking the network structure predominates at higher radiation doses and result in hydrophilicity of the DN hydrogels increases.

\section{Effect of Radiation Doses on Capacitance and Conductivity}

The specific capacitance and conductivity for various radiation doses in dilute $0.5 \mathrm{M} \mathrm{HCl}$ aqueous electrolyte is given in Table 4.

As demonstrated in Table 4, the result clearly shows that the specific capacitance increases stepwise with increasing in radiation dose and it reached a maximum capacitance of $9.774 \mathrm{~F} / \mathrm{g}$ at $80 \mathrm{kGy}$. Thereafter the irradiation dose exceeding $80 \mathrm{kGy}$, the specific capacitance decreased. This can be explained that increasing the specific capacitance is attributed predominance to the synergistic effect of both graphene and polyaniline as previously mentioned. An increase in the radiation dose enhances the energy intensity for initiating the formation of radicals and prolonged the propagation step of the graft copolymerization process, causing to higher the grafting yield of the resulting graphene-polyanilinecellulose crosslinks. These results coincide with the previous result [34]. At higher grafting yield, the incorporation of more polyaniline grafted provides a higher the pseudo-capacitance contribution. The additional formed of free radicals, free electrons and ions entrapped in the DN hydrogels by increasing radiation doses could also have contributed to the increase in capacitance. At the dose above $80 \mathrm{kGy}$, the specific capacitance slightly decreases, that is ascribed to the breakage of the DN hydrogels crosslinks and the decrease of grafting yield due to excess irradiation doses.

Table 4 indicates that the conductivity of the DN hydrogels increases with increasing radiation doses in the range of 40 to $80 \mathrm{kGy}$. As radiation dose increases to a sufficient dose, the conjugations of more polyaniline become a better ionic mobility in these hydrogels networks and allow the conductivity to increase until the optimum value. Free charges, namely polarons and ions could contribute the changes in the conductivity properties [42,43]. At higher radiation doses, a greater number of trapped charges ions and polarons are delocalized in the network polymers thus increase the conductivity. According to Meftah et al. [44] increasing radiation doses could decrease the band gap of conducting polyaniline therefore it can enhance the conductivity. The increasing of crystallinity induced by increasing radiation doses could also have contributed to the increase in the conductivity as mentioned earlier. However, with radiation doses exceeding $80 \mathrm{kGy}$, the conductivity tended to level off. It might be presumed that reducing the mobility chains by highly cross-linked structure diminished the free charges contribution to excess gamma irradiation doses.

\section{CONCLUSION}

The double networks hydrogels based on graphene-polyaniline-cellulose have been successfully synthesized using one pot method by gamma irradiation. The FTIR and XRD analyses confirmed the formation of graphene-polyaniline-cellulose double interpenetrating networks. Increasing the crystallinity during graft copolymerization of aniline onto graphene and cellulose was found by XRD analysis. The results show that the crosslink density increases while the 
swelling degree first increase and then decrease with increasing aniline volume. The crosslink density increased with increasing radiation doses and leveled off around 100 kGy however, the swelling degree shows the opposite trend. This work also demonstrates that the specific capacitance and the conductivity increased by introducing an optimum aniline volume and increasing radiation doses. The synergistic combination of the double layers of graphene and pseudo-capacitance from polyaniline improved the electrochemical properties. This research provided a facile methodology for synthesized the double networks hydrogels and promotes the development of energy storage devices.

\section{ACKNOWLEDGEMENT}

The authors are grateful for the financial support of The Ministry of Research, Technology and Higher Education of the Republic of Indonesia through the INSINAS program. The author would like to thanks to Mrs. Kartini Megasari, Miss Siva Fauziah and Miss Ummu Habibah for contribution help to this research activity.

\section{REFERENCES}

[1] Swantomo, D., Rochmadi, Basuki, K.T., and Sudiyo, R., 2014, Synthesis of smart biodegradable hydrogels cellulose-acrylamide using radiation as controlled release fertilizers, Adv. Mater. Res., 896, 296-299.

[2] Swantomo, D., Basuki, K.T., and Sudiyo, R., 2014, Effect of silica fillers on characterization of celluloseacrylamide hydrogels matrices as controlled release agents for urea fertilizers, Indones. J. Chem., 14 (2), 116-121.

[3] Gao, C., Ren, J., Zhao, C., Kong, W., Dai, Q., Chen, Q., Liu, C., and Sun, R., 2016, Xylan-based temperature/pH sensitive hydrogels for drug controlled release, Carbohydr. Polym., 151, 189197.

[4] Seok, Y.S., Cho, K., Lee, H.J., Chang, S., Lee, H., Kim, J.H., and Koh, W.G., 2016, Highly conductive and hydrated PEG-based hydrogels for the potential application of a tissue engineering scaffold, React. Funct. Polym., 109, 15-22.

[5] Shi, Z., Gao, X., Ullah, M.W., Li, S., Wang, Q., and Yang, G., 2016, Electroconductive natural polymerbased hydrogels, Biomaterials, 111, 40-54.

[6] Song, H.S., Kwon, O.H., Kim, J.H., Conde, J., and Artzi, N., 2017, 3D hydrogel scaffold doped with 2D graphene materials for biosensors and bioelectronics, Biosens. Bioelectron., 89, 187-200.

[7] Ahmed, E.M., 2015, Hydrogel: Preparation, characterization, and applications : A review, J. Adv.
Res., 6 (2), 105-121.

[8] Craciun, G., Manaila, E., and Stelescu, M.D., 2016, Electron beam synthesis and characterization of acrylamide/acrylic acid hydrogels using trimethylolpropane trimethacrylate as cross-linker, J. Chem., 2016, 1470965, 1-14.

[9] Faghihi, S., Karimi, A., Jamadi, M., Imani, R., and Salarian, R., 2014, Graphene oxide/poly(acrylic acid)/gelatin nanocomposite hydrogel: Experimental and numerical validation of hyperelastic model, Mater. Sci. Eng., C, 38, 299305.

[10] Es-haghi, S.S., and Weiss, R.A., 2016, Finite strain damage-elastoplasticity in double-network hydrogels, Polymer, 103, 277-287.

[11] Sabzi, M., Samadi, N., Abbasi, F., Mahdavinia, G.R., and Babaahmadi, M., 2016, Bioinspired fully physically cross-linked double network hydrogels with a robust, tough and self-healing structure, Mater. Sci. Eng., C, 74, 374-381.

[12] Mohammadi, S., Keshvari, H., Eskandari, M., and Faghihi, S., 2016, Graphene oxide-enriched double network hydrogel with tunable physicomechanical properties and performance, React. Funct. Polym., 106, 120-131.

[13] Yuan, L., Wu, Y., Gu, Q., El-hamshary, H., Elnewehy, M., and Mo, X., 2017, Injectable photo crosslinked enhanced double-network hydrogels from modified sodium alginate and gelatin, Int. J. Biol. Macromol., 96, 569-577.

[14] Zhuang, Y., Yu, F., Chen, J., and Ma, J., 2016, Batch and column adsorption of methylene blue by graphene/alginate nanocomposite: Comparison of single-network and double-network hydrogels, $J$. Environ. Chem. Eng., 4 (1), 147-156.

[15] Zhao, Z., Chen, H., Zhang, H., Ma, L., and Wang, Z., 2017, Polyacrylamide-phytic acidpolydopamine conducting porous hydrogel for rapid detection and removal of copper (II) ions, Biosens. Bioelectron., 91, 306-312.

[16] Torres, D.I., Miranda, M.V., Campo, V., and Dall' Orto, V.C., 2017, Chemical one-pot preparation of SBP-PANI-PAA-ethylene glycol diglycidyl ether sensor for electrochemical detection of $\mathrm{H}_{2} \mathrm{O}_{2}$, Sens. Actuators, B, 239, 1016-1025.

[17] Nagamine, K., Chihara, S., Kai, H., Kaji, H., and Nishizawa, M., 2016, Totally shape-conformable electrode/hydrogel composite for on-skin electrophysiological measurements, Sens. Actuators, B, 237, 49-53.

[18] Mi, H., Li, F., He, C., Chai, X., Zhang, Q., Li, C., Li, Y., and Liu, J., 2016, Three-dimensional network structure of silicon-graphene-polyaniline composites as high performance anodes for Lithium-ion batteries, Electrochim. Acta, 190, 
1032-1040.

[19] Smirnov, M.A., Sokolova, M.P., Bobrova, N.V., Kasatkin, I.A., Lahderanta, E., and Elyashevich, G.K., 2016, Capacitance properties and structure of electroconducting hydrogels based on copoly(aniline-p-phenylenediamine) and polyacrylamide, J. Power Sources, 304, 102-110.

[20] Zhang, F., Xiao, F., Dong, Z.H., and Shi, W., 2013, Synthesis of polypyrrole wrapped graphene hydrogels composites as supercapacitor electrodes, Electrochim. Acta, 114, 125-132.

[21] Luo, J., Zhong, W., Zou, Y., Xiong, C., and Yang, W., 2016, Preparation of morphology-controllable polyaniline and polyaniline/graphene hydrogels for high performance binder-free supercapacitor electrodes, J. Power Sources, 319, 73-81.

[22] Pattananuwat, P., and Aht-ong, D., 2017, Controllable morphology of polypyrrole wrapped graphene hydrogel framework composites via cyclic voltammetry with aiding of poly (sodium 4-styrene sulfonate) for the flexible supercapacitor electrode, Electrochim. Acta, 224, 149-160.

[23] Gao, K., Shao, Z., Wu, X., Wang, X., Li, J., Zhang, Y., Wang, W., and Wang, F., 2013, Cellulose nanofibers/reduced graphene oxide flexible transparent conductive paper, Carbohydr. Polym., 97 (1), 243-251.

[24] Kafy, A., Akther, A., Zhai, L., Kim, H.C., and Kim, J., 2017, Porous cellulose/graphene oxide nanocomposite as flexible and renewable electrode material for supercapacitor, Synth. Met., 223, 94100.

[25] Lee, T., Han, M., Lee, S., and Gyu, Y., 2016, Electrically conductive and strong cellulose-based composite fibers reinforced with multiwalled carbon nanotube containing multiple hydrogen bonding moiety, Compos. Sci. Technol., 123, 57-64.

[26] Tian, J., Peng, D., Wu, X., Li, W., Deng, H., and Liu, S., 2017, Electrodeposition of $\mathrm{Ag}$ nanoparticles on conductive polyaniline/cellulose aerogels with increased synergistic effect for energy storage, Carbohydr. Polym., 156, 19-25.

[27] Lay, M., Méndez, J.A., Delgado-Aguilar, M., Bun, K.N., and Vilaseca, F., 2016, Strong and electrically conductive nanopaper from cellulose nanofibers and polypyrrole, Carbohydr. Polym., 152, 361-369.

[28] Ma, L., Liu, R., Niu, H., Wang, F., Liu, L., and Huang, Y., 2016, Freestanding conductive film based on polypyrrole/bacterial cellulose/graphene paper for flexible supercapacitor: Large areal mass exhibits excellent areal capacitance, Electrochim. Acta, 222, 429-437.

[29] lakobson, O.D., Gribkova, O.L., Tameev, A.R., Kravchenko, V.V, Egorov, A.V, and Vannikov, A.V., 2016, Conductive composites of polyaniline- polyacid complex and graphene nanostacks, Synth. Met., 211, 89-98.

[30] Zhang, Y., Heher, P., Hilborn, J., Redl, H., and Ossipov, D.A., 2016, Hyaluronic acid-fibrin interpenetrating double network hydrogel prepared in situ by orthogonal disulfide cross-linking reaction for biomedical applications, Acta Biomater., 38, 23-32.

[31] Mittal, H., Maity, A., and Ray, S.S., 2015, Gum ghatti and poly(acrylamide-co-acrylic acid) based biodegradable hydrogel-evaluation of the flocculation and adsorption properties, Polym. Degrad. Stab., 120, 42-52.

[32] Sharma, K., Kaith, B.S., Kumar, V., Kalia, S., Kumar, V., and Swart, H.C., 2014, Synthesis and biodegradation studies of gamma irradiated electrically conductive hydrogels, Polym. Degrad. Stab., 107, 166-177.

[33] Sharma, K., Kumar, V., Kaith, B.S., Kumar, V., Som, S., Kalia, S., and Swart, H.C., 2015, Synthesis, characterization and water retention study of biodegradable Gum ghattipoly(acrylicacid-aniline) hydrogels, Polym. Degrad. Stab., 111, 20-31.

[34] Swantomo, D., Rochmadi, Basuki, K.T., and Sudiyo, R., 2013, Synthesis and characterization of graft copolymer rice straw cellulose-acrylamide hydrogels using gamma irradiation, Atom Indones., 39, 57-64.

[35] Omidian, H., Hasherni, S., Askari, F., and Nafisi, S., 1994, Swelling and crosslink density measurements for hydrogels, Iran. J. Polym. Sci. Technol., 3, 115-119.

[36] Wang, G., Xing, W., and Zhuo, S., 2012, The production of polyaniline/graphene hybrids for use as a counter electrode in dye-sensitized solar cells, Electrochim. Acta, 66, 151-157.

[37] Ameen, S., Akhtar, M.S., and Shik, H., 2012, Hydrazine chemical sensing by modified electrode based on in situ electrochemically synthesized polyaniline/graphene composite thin film, Sens. Actuators, B, 173, 177-183.

[38] Kumar, N.A., Choi, H.J., Shin, Y.R., Chang, D.W., Dai, L., and Baek, J.B., 2012, Polyaniline-grafted reduced graphene oxide for efficient electrochemical, ACS Nano, 6 (2), 1715-1723.

[39] Moharram, M.A., Ereiba, K.M.T., El Hotaby, W., and Bakr, A.M., 2015, Thermal degradation studies of graphene oxide polymer composite, Middle East J. Appl. Sci., 05, 23-30.

[40] Moghadam, M.H.M., Sabury, S., Gudarzi, M.M., and Sharif, F., 2014, Graphene oxide-induced polymerization and crystallization to produce highly conductive polyaniline/graphene oxide composite, J. Polym. Sci., Part A: Polym. Chem., 
52 (11), 1545-1564.

[41] Rimdusit, S., Somsaeng, K., Kewsuwan, P., Jubsilp, C., and Tiptipakorn, S., 2012, Comparison of gamma radiation crosslinking and chemical crosslinking on properties of methylcellulose hydrogel, Eng. J., 16, 15-28.

[42] Harun, M.H., Saion, E., Kassim, A., Hussain, M.Y., Mustafa, I.S., and Omer, M.A.A., 2008, Temperature dependence of AC electrical conductivity of PVA-PPy- $\mathrm{FeCl}_{3}$ composite polymer films, Malaysian Polym. J., 3 (2), 24-31.
[43] Dudić, D., Luyt, A.S., Marinković, F., Petronijević, I., Dojčilović, J., and Kostoski, D., 2015, The effect of gamma irradiation on the thermal behavior of dielectric properties of linear low-density/carbon black semiconductive composites, Radiat. Phys. Chem., 107, 89-94.

[44] Meftah, A.M., Gharibshahi, E., Soltani, N., Yunus, W.M.M., and Saion, E., 2014, Structural, optical and electrical properties of PVA/PANI/Nickel nanocomposites synthesized by gamma radiolytic method, Polymers, 6 (9), 2435-2450. 